\title{
Stature estimation from forearm length: an anthropological study in Iranian medical students
}

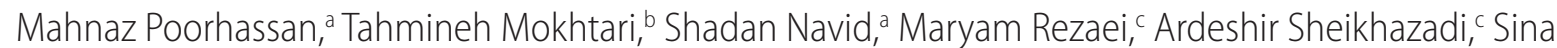 \\ Mojaverrostami, ${ }^{a}$ Gholamreza Hassanzadeha
}

\author{
aDepartment of Anatomy, School of Medicine, Tehran University of Medical Sciences, Tehran, Iran. \\ bDepartment of Anatomy, School of Medicine, Semnan University of Medical Sciences, Tehran, Iran. \\ 'Department of Forensic Medicine, School of Medicine, Tehran University of Medical Sciences, Tehran, Iran. \\ Correspondence to Gholamreza Hassanzadeh (email: hassanzadeh@tums.ac.ir). \\ (Submitted: 12 February 2017 - Revised version received: 28 March 2017 - Accepted: 05 May 2017 - Published online: 26 September 2017)
}

\begin{abstract}
Objective Stature estimation is an important biological factor for forensic medicine to identify an individual. Forearm length can be used for the prediction of the stature in different populations. In the present study, the relation between forearm length and height was evaluated.

Methods In a cross sectional study, a sample of 100 males and 100 females (aged 18 to 25 years) medical students from Iranian population was randomly entered into the study. Left forearm was measured by measuring tape. Stature was measured in standard position. The linear regression analysis was used to estimate the relation between forearm length and the stature.

Results The mean age of subjects was $22 \pm 2.21$ years. Mean age of male cases was $22 \pm 2.8$ years and female cases was $21.9 \pm 1.81$ years and there wasn't significant difference in the age of sex groups $(P=0.314)$. A significant differences were recorded in the height and forearm length of subjects between two sex groups $(P=0.0001)$. There was a correlation between height and forearm length of all subjects $(r=0.643, P=0.0001)$. According to the linear regression, there was a relation between height and upper arm length of subject in all cases. Conclusion According to the results, forearm length was a moderate predictor for stature estimation of medical students in Iranian population.

Keywords anthropology, stature, forearm length, Iranians
\end{abstract}

\section{Introduction}

Identification of decomposed human body remains is an important goal in forensic sciences. Age sex, stature and ancestry are biological characteristics of individuals which can be evaluated from skeleton remains of human many years after death. ${ }^{1-3}$ Stature is affected by genes and environment and can show the racial differences in different populations. ${ }^{4}$ Stature estimation can be performed from the long bones of limbs with the best results. ${ }^{5}$ Using the body parts for predicting the biological characteristics of individuals can confirm the results of forensic identifications. ${ }^{6,7}$ In this way, anthropological studies on the body parts are widely used in criminal cases, terrorist attacks and natural disasters to identify victims. ${ }^{8,9}$ Anatomical methods based on reconstruction of entire body can't be useful for stature estimation. However, stature predicting from body parts found in these events can be performed by mathematical methods and linear regression equations can find the relation between body parts and stature..$^{10-12}$ According to literature, the relation between stature and upper limb dimensions such as shoulder width, arm, forearm, hand, figures were studied in previous studies. ${ }^{13-19}$

In this study, the relation between forearm length and stature was evaluated by regression equation in Iranian medical students.

\section{Methods and Materials}

In a cross-sectional study, from October 2014 to May 2015, 200 healthy subjects (100 males and 100 females, aged
18 to 25 years) were randomly selected from middle socioeconomic status population. The subjects with skeletal deformities or pathological changes were excluded. All measurements were performed in standard position by standard anthropological instruments and all dimensions were taken in the unit of $1 \mathrm{~cm}$. For avoiding interpersonal errors, all measurements were performed by a single person in a fixed time from 1:00 pm to 3:00 pm. All measurements were repeated.

\section{Stature Estimation}

Stadiometer was used for stature (standing height) measurement. All subjects were in standard anatomical position, and their head was held in the Frankfort horizontal plane. Stature was defined as maximum distance from vertex of subject to the floor.

\section{Forearm Length}

The standard measuring tape was used for forearm length measurement. Forearm was in arm flexed position. Forearm length was defined as distance from the tip of olecranon and mid-point between radius and ulnar tuberosity. Left limb was used for estimations.

\section{Statistical Analysis}

Mean \pm standard deviation was used for descriptive data. $T$-test was used for finding the differences between two sex groups. In addition, the correlations between quantitative data were checked. Linear regression equation analysis was used to find the relation between quantitative data. 
Table 1. Comparison of stature and forearm length in males and females in Iranian medical students

\begin{tabular}{|c|c|c|c|c|c|c|c|c|}
\hline & \multicolumn{7}{|c|}{ Sex } & \\
\hline & \multicolumn{4}{|c|}{ Male } & \multicolumn{4}{|c|}{ Female } \\
\hline & Mean & SD* & Max & Min & SD* & Max & Min & Mean \\
\hline Age & 19.73 & 1.08 & 22 & 18 & 20.62 & 2.07 & 26 & 18 \\
\hline Stature (cm) & 180.02 & 5.73 & 196 & 171 & 162.37 & 5.76 & 176 & 150 \\
\hline Forearm length $(\mathrm{cm})$ & 28.98 & 1.92 & 33 & 26 & 25.90 & 1.79 & 29 & 22 \\
\hline
\end{tabular}

*Standard Deviation; Max, Maximum; Min, Minimum.

Table 2. Linear regression for estimation of stature from upper arm length of medical students

\begin{tabular}{|c|c|c|c|}
\hline Regression equation & \pm SEE & $R^{2}$ & $P$-value \\
\hline$S=73.69+3.54 \times$ Forearm length $(\mathrm{cm})$ & 6.21 & 0.65 & 0.0001 \\
\hline $\begin{aligned} S_{M}= & 118.916+2.108 \times \text { Forearm } \\
& \text { length }(\mathrm{cm})\end{aligned}$ & 4.08 & 0.501 & 0.0001 \\
\hline $\begin{aligned} S_{F}= & 112.461+1.109268 \times \text { Forearm } \\
& \text { length }(\mathrm{cm})\end{aligned}$ & 4.64 & 0.36 & 0.0001 \\
\hline
\end{tabular}

F, female; M, male; $R^{2}$, Coefficient of Determination; SEE, Standard Error of Estimate; $S$, stature.

\section{Results}

The mean age of subjects was $22 \pm 2.21$ years. Mean age of male cases was $22 \pm 2.8$ years and female cases was $21.9 \pm 1.81$ years and according to $t$-test analysis. There wasn't a significant difference in the age of sex groups $(P=0.314)$.

Mean standing height of all subjects was $171.7 \pm 10.19 \mathrm{~cm}$. Mean height of males and females was $180.48 \pm 5.76 \mathrm{~cm}$ and $162.92 \pm 4.42 \mathrm{~cm}$, respectively. A significant differences were recorded in the height of subjects between two sex groups ( $P=0.0001$, and Table 1$)$. As Table 1 shows, there was significant difference in the forearm length of sex groups $(P=0.0001)$. There was a correlation between height and forearm length of subjects ( $r=0.643, P=0.0001)$. There was a correlation between height and forearm length of subjects $(r=0.427, P=0.002)$. However, this correlation wasn't recorded for female subjects $(r=0.142, P=0.325)$. According to the linear regression, there was a relation between height and upper arm length of subject in all cases. In addition, there was a relation between stature and forearm length in male subjects. However, this relation wasn't recorded for female subjects (Table 2).

\section{Discussion}

Stature estimation is one of the most important factors in forensic and legal medicine for the identification of individual and in anthropological research in forensic examinations, prediction of stature from remained body segments is important. $^{20,21}$ Various studies were conducted to evaluate the relation between stature and upper limb segments in Iran and other countries. ${ }^{13,21,22}$

In this study, 200 subjects were selected randomly from healthy population without skeletal abnormalities from medical students. The mean age was similar in sex groups, and this could help to have a population with normal distributions in age factor.
According to the linear regression, there was a moderate relation between stature and forearm length $(S=111.48+$ $2.261 \times$ Forearm length $\left.(\mathrm{cm}), R^{2}=0.41, \mathrm{SEE}=7.85\right)$.

Mathematical methods such as linear regression are the easiest and reliable methods for predicting the relation between stature and body segments. ${ }^{22}$ Akhlghi et al. (2012) find the correlation between forearm length and stature $(r=0.580)$ and showed that this factor is a poor predictor for stature estimation in comparison with other factors such as upper limb length $(r=0.635)$, arm length $(r=0.602)$, hand length $(r=0.695)$. This correlation was more reliable $(r=0.643)$ and superior to the upper limb length and arm length in the present study. ${ }^{13}$

Ilayperuma et al. (2010) could find a model for prediction of stature form forearm length in Sri Lankan population. Their formula for all subjects was Height $=97.252+2.645$ (ulna length). ${ }^{23}$ Singh et al. (2013) used forearm length for prediction of stature in north Indians.

According to the results, mean stature was higher in male subjects than females. Srivastava et al. (2010), ${ }^{21}$ Ilayperuma et al. ${ }^{23}$ demonstrated similar results in their studies. In addition, sexual dimorphism was observed in the results and forearm length was longer than female subjects. According to Akhlaghi et al. (2012) study, mean the forearm length was longer in male subjects than female subjects. ${ }^{13}$ This result confirmed the results of the present study. However, the mean forearm length obtained from this study was longer than results from their study According to dimorphism, the separated formula were reported for male subjects. However, this formula had a poor value for predicting the stature from forearm length in medical students $(r=0.425)$. For female subjects, the formula wasn't obtained.

Akhlghi et al. (2012) find the correlation between forearm length and stature in male $(r=0.354)$ and females $(r=0.299)$ in Iranian population. This correlation was more reliable for male subjects in the present study $(r=0.643)$. In addition, Ilayperuma et al. (2010) could find a model for prediction of stature form forearm length for males $(r=0.66)$ and females $(r=0.76)$ in Sri Lankan population. In addition, Singh et al. (2013) used forearm length for prediction of stature in north Indians. Correlation confection $(r)$ was 0.601 for males and 0.531 for females. ${ }^{24}$ Their results were more reliable than the results of the present study.

According to the results, forearm length was a moderate predictor for stature estimation of medical students in Iranian population. In addition, this factor is a poor predictor for male Iranians and is not suitable for female Iranians for stature estimation. 


\section{References}

1. Krishan K, Sharma A. Estimation of stature from dimensions of hands and feet in a North Indian population. J Forensic Leg Med. 2007; 14:327-332.

2. Cordeiro C, Muñoz-Barús JI, Wasterlain S, Cunha E, Vieira DN. Predicting adult stature from metatarsal length in a Portuguese population. Forensic Sci Int. 2009:193:131. e1-e4.

3. Scheuer L. Application of osteology to forensic medicine. Clin Anat 2002:15:297-312.

4. Patel SM, Shah GV, Patel SV. Estimation of height from measurement of foot length in Gujarat region. J Anat Soc India. 2007;56:25-27.

5. Trotter M, Gleser GC. Estimation of stature from long bones of American Whites and Negroes. Am J Phys Anthropol. 1952;10:463-514.

6. Cattaneo C. Forensic anthropology: developments of a classical discipline in the new millennium. Forensic Sci Int. 2007;165(2):185-193.

7. Kharoshah MAA, Almadani O, Ghaleb SS, Zaki MK, Fattah YAA. Sexua dimorphism of the mandible in a modern Egyptian population. J Forensic Leg Med. 2010;17:213-215.

8. Menezes RG, Nagesh K, Monteiro FN, Kumar GP, Kanchan T, Uysal S, et al. Estimation of stature from the length of the sternum in South Indian females. J Forensic Legal Med. 2011;18:242-245.

9. Singh S, Nair SK, Anjankar V, Bankwar V, Satpati D, Malik Y. Regression equation for estimation of femur length in central Indians from intertrochanteric crest. J Indian Acad Forensic Med. 2013;35:223-226.

10. Jee $\mathrm{S}-\mathrm{C}$, Yun $\mathrm{MH}$. Estimation of stature from diversified hand anthropometric dimensions from Korean population. J Forensic Leg Med. 2015;35:9-14.

11. Cheng JC, Leung S, Chiu B, Tse P, Lee C, Chan A, et al. Can we predict body height from segmental bone length measurements? A study of 3,647 children. J Pediatr Orthop. 1998:18:387-393.

12. Sheikhazadi A, Hassanzadeh G, Mokhtari Tahmineh, Sheikhazadi Elham, Saber Anary Seyed Hossein, et al. Stature estimation from percutaneous tibia height: study of Iranian medical students. Joint Bone Sci J. 2015;2:121-127.
13. Akhlaghi M, Hajibeygi M, Zamani N, Moradi B. Estimation of stature from upper limb anthropometry in Iranian population. J Forensic Leg Med. 2012;19:280-284.

14. Ahmed AA. Estimation of stature from the upper limb measurements of Sudanese adults. Forensic Sci Int. 2013;228:178. e1-e7.

15. Shah RK, Patel JP, Patel BG, Kanani SD, Patel MD. Estimation of stature from foot length and hand length measurements in Gujarat region. Natl J Integr Res Med. 2014:5:16-19.

16. Patel JP, Patel BG, Shah RK, Bhojak NR, Desai JN. Estimation of stature from hand length in Gujarat region. NHL J Med Sci. 2014;3:41-44.

17. Shah T, Patel M, Nath S, Menon SK. A Model for construction of height and sex from shoulder width, arm length and foot length by regression method. J Forensic Sci Criminol. 2015:3:102.

18. Forman MR, Zhu Y, Hernandez LM, Himes JH, Dong Y, Danish RK, et al. Arm span and ulnar length are reliable and accurate estimates of recumbent length and height in a multiethnic population of infants and children under 6 years of age. J Nutr. 2014;144:1480-1487.

19. Kumar S, Shetty P. Estimation of stature from middle finger length-in Salem region. Indian J Forensic Med Toxicol. 2014;8:30-33.

20. Krishan K, Kanchan T, Sharma A. Multiplication factor versus regression analysis in stature estimation from hand and foot dimensions. J Forensic Leg Med. 2012:19:211-214.

21. Srivastava A, Sahai M. Estimation of stature by anthropometric examination of forearm and hand. J Indian Acad Forensic Med. 2010:32:62-65.

22. Ilayperuma I, Nanayakkara G, Palahepitiya N. A model for the estimation of personal stature from the length of forearm. Int J Morphol. 2010;28:1081-1086.

23. Ilayperuma I, Nanayakkara B, Palahepitiya K. A model for reconstruction of personal stature based on the measurements of foot length. Galle Med J. 2008;13:6-9.

24. Singh B, Kaur M, Kaur J, Singh M, Batra A. Estimation of stature from forearm length in north Indians-an anthropometric study. Int J Basic Appl Med Sci. 2013;3:201-204. 